\title{
Age, growth and body condition of big-scale sand smelt Atherina boyeri Risso, 1810 inhabiting a freshwater environment: Lake Trasimeno (Italy)
}

\author{
M. Lorenzoni ${ }^{(1)}$, D. Giannetto ${ }^{(2), \star}$, A. Carosi ${ }^{(1)}$, R. Dolciami $i^{(3)}$, L. Ghetti ${ }^{(4)}$, \\ L. Pompei ${ }^{(1)}$
}

Received September 24, 2014

Revised January 29, 2015

Accepted January 29, 2015

Key-words: Population dynamics, Lee's phenomenon, fishery management, introduced species, Lake Trasimeno

\section{ABSTRACT}

The age, growth and body condition of the big-scale sand smelt (Atherina boyeri) population of Lake Trasimeno were investigated. In total, 3998 specimens were collected during the study and five age classes (from $0+$ to $4+$ ) were identified. From a subsample of 1017 specimens, there were 583 females, 411 males and 23 juveniles. The equations between total length $(T L)$ and weight $(W)$ were: $\log _{10} W=-2.326+$ $3.139 \log _{10} T L$ for males and $\log _{10} W=-2.366+3.168 \log _{10} T L$ for females. There were highly significant differences between the sexes and for both sexes the value of $b$ (slope of the log (TL-W regression) was greater than 3 (3.139 for males and 3.168 for females), indicating positive allometric growth. The parameters of the theoretical growth curve were: $T L_{t}=10.03 \mathrm{~cm} ; k=0.18 \mathrm{yr}^{-1}, t_{0}=-0.443 \mathrm{yr}$ and $\Phi^{\prime}=1.65$. Monthly trends of overall condition and the gonadosomatic index (GSI) indicated that the reproductive period occurred from March to September. Analysis of back-calculated lengths indicated the occurrence of a reverse Lee's phenomenon. This could be a symptom of predation or competition, with consequences for young specimens with slower growth and smaller size.

\section{RÉSUMÉ}

Âge, croissance et condition physique des athérines Atherina boyeri Risso, 1810 d'un milieu d'eau douce : le lac Trasimène (Italie)

\section{Mots-clés : dynamique de population, phénomène de Lee, gestion de la pêche,}

L'âge, la croissance et la condition physique de la population d'athérine (Atherina boyeri) du lac Trasimène ont été étudiés. Au total, 3998 échantillons ont été prélevés au cours de l'étude et cinq classes d'âge (de 0+ à 4+) ont été identifiées. D'un sous-échantillon de 1017 spécimens le sexe a été déterminé, soit 583 femelles, 411 mâles et 23 juvéniles. Les équations entre la longueur totale $\left((T L)\right.$ et le poids $(W)$ sont : $\log _{10} W=-2,326+3,139 \log _{10} T L$ pour les mâles et $\log _{10} W=-2,366+3,168 \log _{10} T L$ pour les femelles. II y a une différence très significative entre les sexes et pour les deux sexes la valeur de b (pente de la régression) est supérieure à 3 (3,139 pour les mâles et 3,168 pour les femelles),

(1) Dipartimento di Chimica, Biologia e Biotecnologie, Università di Perugia, via Elce di Sotto, 06123 Perugia, Italy

(2) Department of Biology, Faculty of Sciences, Muğla Sitki Koçman University, 48000 Muğla, Turkey

(3) Provincia di Perugia, Centro Ittiogenico del Trasimeno, Via della Palazzetta, 06063 S. Arcangelo, Italy

(4) Regione dell'Umbria, Sezione Tutela del Patrimonio Ittico e Pesca Sportiva, Piazza del Bacio, 06123 Perugia, Italy

* Corresponding author: danielagiannetto@gmail.com 
espèce introduite, lac Trasimène ce qui indique une croissance allométrique positive. Les paramètres de la courbe de croissance théorique sont : $T L_{t}=10,03 \mathrm{~cm} ; k=0,18 \mathrm{yr}^{-1}, t_{0}=-0,443 \mathrm{yr}$ et $\Phi^{\prime}=$ 1,65. Les tendances mensuelles de l'état général et de l'indice gonado-somatique (GSI) indiquent que la période de reproduction a eu lieu de mars à septembre. L'analyse des longueurs rétro-calculées indique la présence d'un phénomène de Lee inversé. Ce pourrait être un symptôme de la prédation ou de la concurrence ayant des conséquences sur les jeunes spécimens à croissance plus lente et de plus petite taille.

\section{INTRODUCTION}

The big-scale sand smelt, Atherina boyeri Risso 1810, is a small inshore species common in the Mediterranean (along the Mediterranean coasts, and Black, Azov and Caspian Sea basins) and in the north-east Atlantic (from the Azores to the north-west coast of Scotland) (Quignard and Pras, 1986; Whitehead et al., 1986; Bianco et al., 2013). This species mainly inhabits coastal and estuarine waters and lagoons, over a wide range of salinities (from freshwater to hypersaline) and, more rarely, freshwaters (Freyhof and Kottelat, 2008). A few permanent freshwater resident populations have also been reported from Santo André lagoon (Iberian Peninsula) and Trichonis Lake (Greece) (Freyhof and Kottelat, 2008). Moreover, this euryhaline species was successfully introduced into many lakes for stock enhancement purposes or due to accidental transfer (Economidis et al., 2000; Leonardos, 2001; Bianco et al., 2013).

In Italy, the species is native but its original range has been expanded by introductions in many lakes (Bianco et al., 2013). In Lake Trasimeno the big-scale sand smelt was introduced, probably accidentally, in 1920 (Moretti et al., 1959) together with juveniles of other species of commercial interest. Since 1928, when the species started to be caught by commercial fishermen (Moretti et al., 1959), the big-scale sand smelt gained increasing commercial value. Almost irrelevant in the total catch until 1980 (Mearelli et al., 1990), in the following years the big-scale sand smelt has become a primary source for commercial catches of local fishermen, representing 29\% of the total catch in 1995-2004 (Lorenzoni and Ghetti, 2012). Nowadays, the big-scale sand smelt is the dominant species in the fish community of Lake Trasimeno, where it represents more than $50 \%$ of the total catch (Pompei et al., 2012a) and the main source of fishing revenues.

Although several studies on the age and growth of big-scale sand smelt have been reported in the literature, only a few have focused on populations inhabiting lakes (Mantilacci et al., 1990; Leonardos, 2001, Özeren, 2009). The aim of this study was therefore to evaluate the age, growth and body condition of the big-scale sand smelt in Lake Trasimeno.

\section{MATERIALS AND METHODS}

Lake Trasimeno is located within the Tiber River basin in Central Italy (Figure 1) $\left(43^{\circ} 9^{\prime} 11^{\prime \prime} \mathrm{N}\right.$ and $\left.12^{\circ} 15^{\prime} \mathrm{E}\right)$. It is the fourth largest lake in Italy $\left(124.3 \mathrm{~km}^{2}\right)$ and the largest Italian laminar lake due to its shallowness (average depth: $4.72 \mathrm{~m}$; max. depth: $6.3 \mathrm{~m}$ ) (Mearelli et al., 1990). Lake Trasimeno is listed as a Site of Community Interest (SCI) and Special Protection Area (SPA) within the Natura 2000 European network and it was assessed as a Regional Park. The lake is characterised by a Mediterranean climate and its seasonal level is quite variable (in 2012 from $-92 \mathrm{~cm}$ to $-154 \mathrm{~cm}$ during summer relative to the reference level) because water is supplied by short intermittent streams that tend to dry up during the summer season (Pompei et al., 2012b). The water temperature is almost the same as the air temperature, and in summer it can exceed $30{ }^{\circ} \mathrm{C}$; thermal stratification is usually absent (Lorenzoni et al., 2002b). Lake Trasimeno is classified as meso-eutrophic (Mearelli et al., 1981; Giovanardi et al., 1995). 


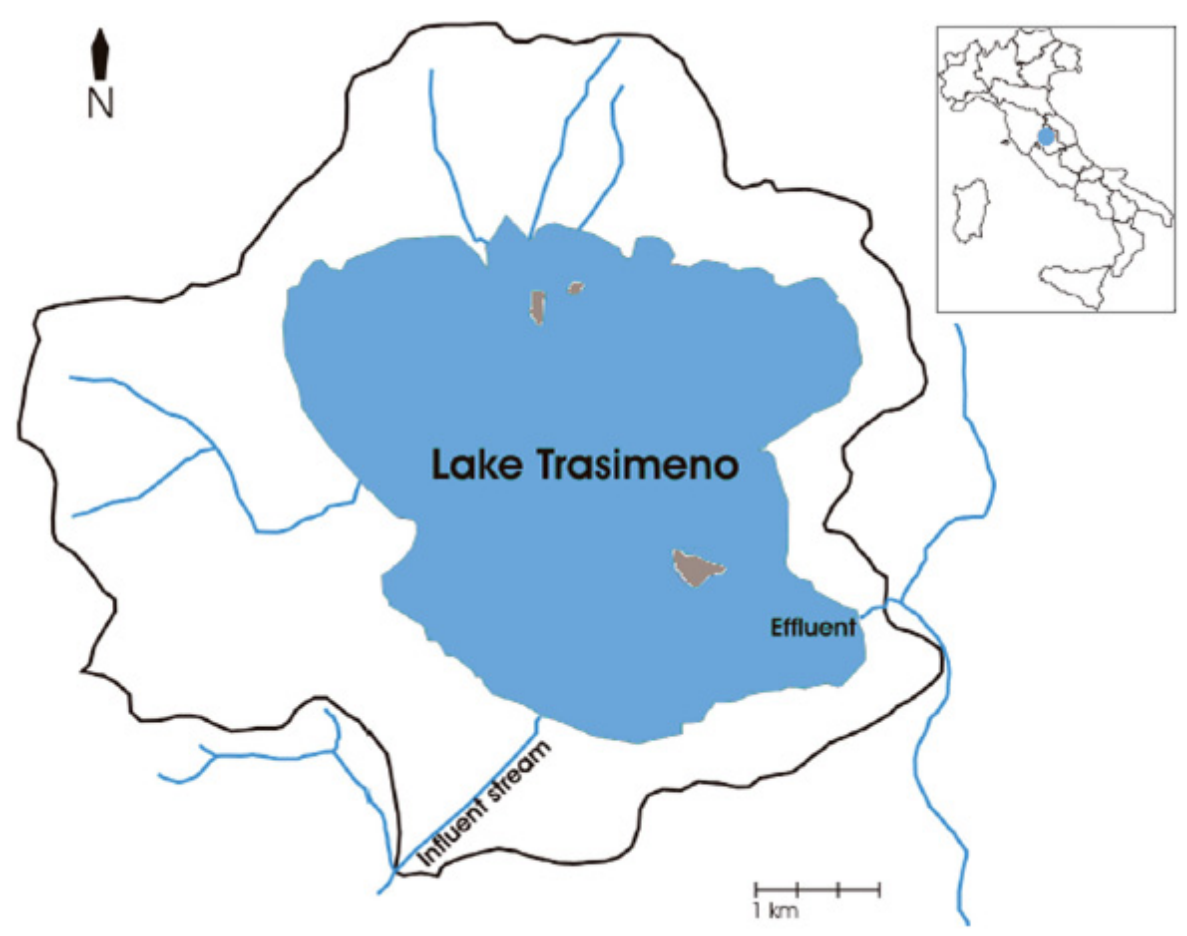

Figure 1

Map of Italy showing the localization of the study area Trasimeno lake (blue dot).

With regard to fish fauna, the introduction of exotic species together with the fluctuating hydrological regime of the lake and the impact of fisheries have probably contributed to severe alteration of the native fish community (Mearelli et al., 1990; Lorenzoni et al., 2006). Currently, this comprises 19 species, only five of which are native: pike Esox lucius Linnaeus, 1758; cavedano chub Squalus squalius (Bonaparte, 1837); tench Tinca tinca (Linnaeus, 1758); rudd Scardinius erythrophthalmus (Linnaeus, 1758) and eel Anguilla anguilla (Linnaeus, 1758). Among the introduced species, together with some fishes of commercial interest (i.e. European perch Perca fluviatilis Linnaeus, 1758 and largemouth bass Micropterus salmoides Lacepede, 1802) other species including goldfish Carassius auratus (Linnaeus, 1758) and topmouth gudgeon Pseudorabora parva (Temminck and Schlegel, 1846) are invasive and considered dangerous for the lake's ecosystem (Lorenzoni et al., 2007). In fact, the latter species are among the world's most invasive fish and assessed as potential pests (Froese and Pauly, 2012). Specifically, topmouth gudgeon, which was first recorded in the lake in the late '90s, can now be considered acclimated and increasing in abundance (Lorenzoni et al., 2010). The goldfish is currently the most caught cyprinid species in the lake and its introduction has probably led to the decline of the native tench population (Lorenzoni and Ghetti, 2012). Early maturity, ability to reproduce by gynogenesis, high fecundity and absence of predators in Lake Trasimeno are the main characteristics thought to have determined its success (Lorenzoni et al., 2007).

\section{> COLLECTION OF SPECIMENS}

Specimens of big-scale sand smelt were randomly taken from professional fishermen's catches twice a month from January 2012 to January 2013. Samples were collected by means of fyke nets, cat nets and gill nets (mesh sizes 5, 6.25 and $8 \mathrm{~mm}$ ) placed in different locations across the lake.

For all specimens, total length $(T L)$ and standard length $(S L)$ were measured to the nearest $0.1 \mathrm{~cm}$, and weight to the nearest $0.1 \mathrm{~g}$ (Anderson and Neumann, 1996) and a sample of 
scales was collected from each specimen for age determination. All scales were stored in ethanol (33\%) and later observed under a stereo microscope using the image-analysis system IAS 2000. Age was determined by the scalimetric method (Bagenal, 1978) and further validated through analysis of the length-frequency distribution (Britton et al., 2004). For a subsample of 1017 individuals randomly selected each month, sex was determined through the macroscopic observation of gonads.

\section{Growth estimation and back-calculation}

The relationship between $S L$ and $T L$ was established for the total sample and separately according to sex by linear regression analysis. Analysis of covariance (ANCOVA) was then used to test differences between the sexes.

The total length-weight relationship $(T L-W)$ was estimated by the least-squares method (Ricker, 1975) based on the logarithmic equation:

$$
\log _{10} W(\mathrm{~g})=a+b \log _{10} T L(\mathrm{~mm}) .
$$

The $T L-W$ relationship was fitted both to the total sample and separately to males and females, and differences between the sexes were assessed by ANCOVA. The standard error was calculated for the slope $(b)$ of the relationship and isometric growth was tested through Student's $t$-test.

Back-calculated lengths (BCLs) were estimated by examining four scales from each fish based on a subsample of 218 specimens collected during the winter months and covering all age classes for both sexes. For all scales, the radius $\left(S_{r}\right.$ : from the centre to the anterior edge of the scale) and the radius of the age rings $\left(S_{t}\right)$ were measured along the major axis $( \pm 0.01 \mathrm{~mm})$ (Bagenal, 1978) with an image-analysis system. For each specimen, the arithmetic mean of the four measurements was then used for further analysis.

The relationship between total body length $(T L)$ and scale radius $\left(S_{r}\right)$ was defined by the linear regression model (Devries and Frie, 1996):

$$
T L=a+b S_{r}
$$

which was fitted separately to the overall sample and according to sex. Differences between the regressions calculated for males and females were then tested by ANCOVA.

Length at age $\left(L_{t}\right)$ was back-calculated according to the Fraser-Lee model (Bagenal and Tesch, 1985):

$$
L_{t}=a+S_{t} S_{r}^{-1}(T L-a)
$$

on the total sample and separately for males and females, with differences between the sexes tested by ANCOVA.

Theoretical growth was estimated by the von Bertalanffy growth curve model (von Bertalanffy, 1938):

$$
T L_{t}=L_{\infty}\left(1-\mathrm{e}^{-k\left(t-t_{0}\right)}\right)
$$

where $T L_{t}$ is the total length of the fish at time $t, L_{\infty}$ the theoretical maximum length $(\mathrm{cm}), k$ the rate of approach to $L_{\infty}$, and $t_{0}$ the theoretical age at which $T L_{t}=0$. The values of BCLs from the last annulus were considered (after Vaughan and Burton, 1994). Also, the index of growth performance $\left(\Phi^{\prime}\right)$ was calculated by the equation of Pauly and Munro, (1984):

$$
\Phi^{\prime}=\log _{10} k+2 \log _{10} L_{\infty}
$$

where $k$ and $L_{\infty}$ are the growth parameters of the von Bertalanffy model. Finally, the BCLs at the first annulus $\left(L_{1}\right)$ of the older specimens $(n=1,2,3$ and 4$)$ were compared by analysis of variance (ANOVA).

To inspect the occurrence of Lee's phenomenon (Bagenal, 1978), the BCLs reached at the various ages by the specimens at age $t$ were compared with those of the older fish $(t+i)$ (Bagenal, 1978) by means of the U-Mann test. Lee's phenomenon is defined as the tendency for BCLs at any age to be smaller, the larger the fish from which they are calculated. In contrast, an inverse Lee's phenomenon is observed when the BCLs are greater, the larger the fish from which they are derived (Bagenal, 1978). 


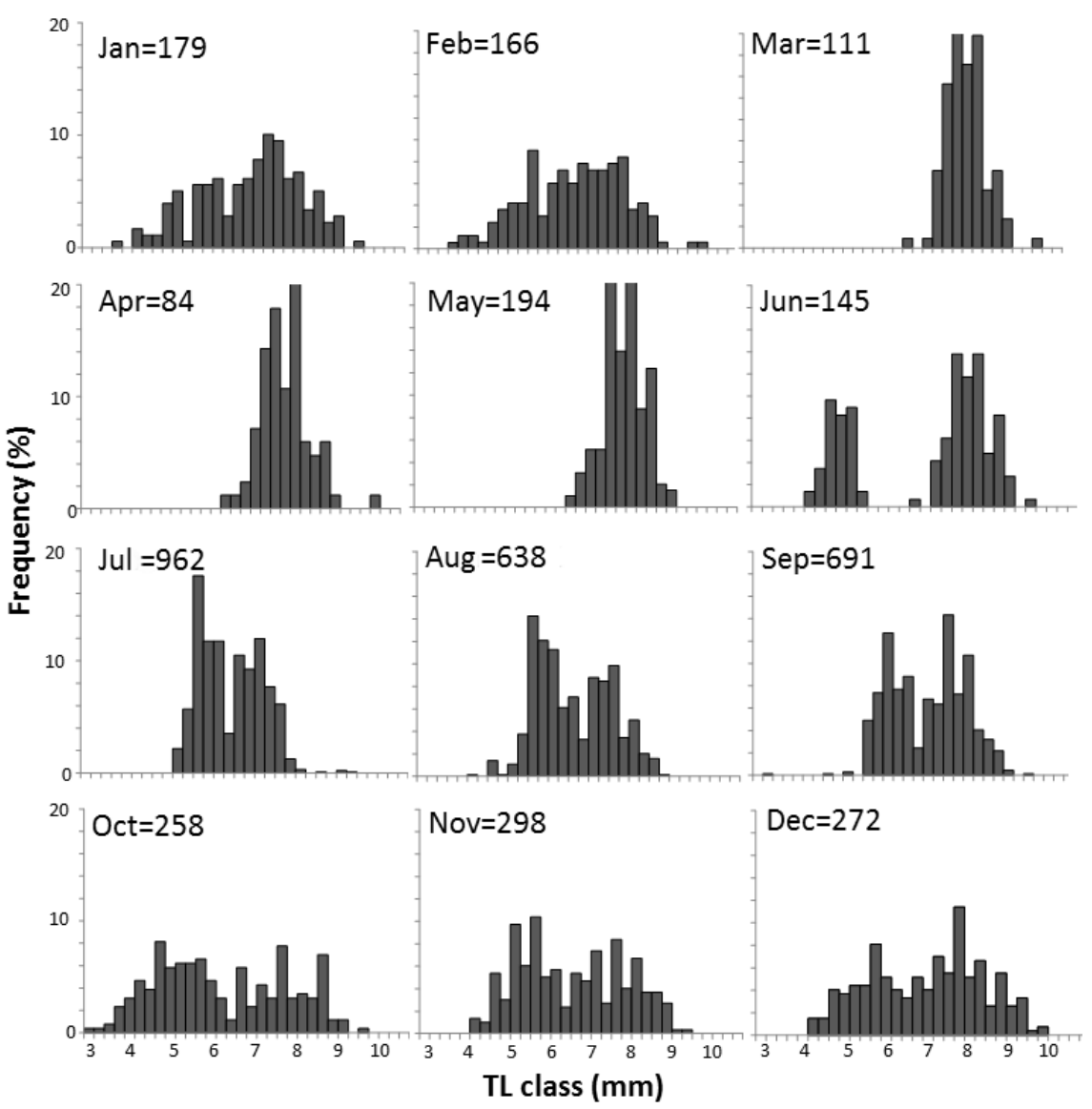

Figure 2

Monthly length distribution of the total sample of individuals of Atherina boyeri caught in Trasimeno lake.

\section{> ESTIMATION OF BODY CONDITION}

Body condition was estimated by the relative condition factor (Le Cren, 1951):

$$
K n=100 W\left(a T L^{b}\right)^{-1}
$$

where $a$ and $b$ are the coefficients of the TL-W equation estimated on the total sample. Relative condition was also calculated using somatic weight (i.e. without considering gonad weight):

$$
K s=(W-W g)\left(a T L^{b}\right)^{-1}
$$

where $W g$ is the gonad weight. Differences between $K n$ and $K s$ during the year were then assessed to investigate the influence of reproduction on the overall health of specimens and to collect information on the reproductive period of the population. This was further explored by analysing the trend of the gonadosomatic index (GSI) of females throughout the year, calculated as (Ricker, 1975):

$$
G S I=100 W g / W .
$$

\section{RESULTS}

\section{> OVERALL POPULATION CHARACTERISTICS}

In total, 3998 specimens of $A$. boyeri were collected during the study. The size of fish ranged from 2.80 to $10.10 \mathrm{~cm}$ (mean $\pm S E=6.68 \pm 1.15$ ) and weight from 0.15 to $8.20 \mathrm{~g}$ (mean \pm $S E=2.30 \pm 1.19$ ). From the monthly length distribution of the total sample (Figure 2) five 


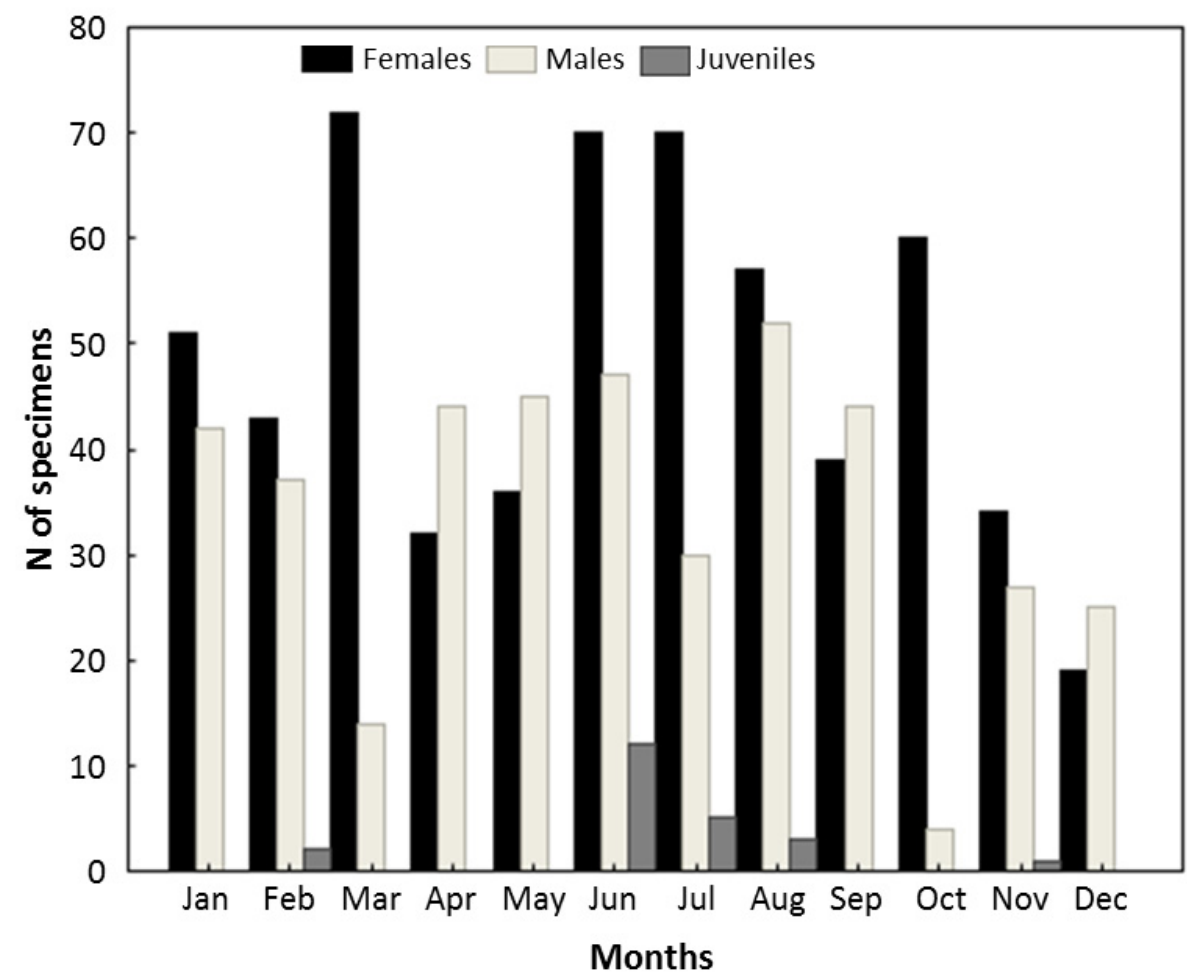

Figure 3

Monthly sex composition of the subsample of 1017 individuals of Atherina boyeri in Trasimeno lake.

age classes from 0+ to 4+ were identified. Based on a subsample of 1017 specimens, sex was determined as follows: 583 females, 411 males and 23 juveniles (Figure 3). Females were longer, older and heavier than males and the differences between the sexes were highly significant in Student's $t$-test for all parameters $(T L(\mathrm{~mm}): t=67.08, p<0.01 ; W(\mathrm{~g}): t=$ 109.60, $p<0.01$; age: $t=62.77 ; p<0.01$ ). The observed sex ratio was 0.70:1 (M:F) with a highly significant difference on chi-square analysis $\left(\chi^{2}=29.763, p<0.01\right)$. Males were more abundant in the earlier classes (M:F ratio $=1.43: 1$ for $0+$ and 1.22:1 for $1+$ ), whereas females became more numerous with increasing age (M:F ratio $=0.76: 1$ for $2+$ and $0.59: 1$ for $3+)$, so that class $4+$ consisted almost exclusively of females $(\mathrm{M}: \mathrm{F}$ ratio $=0.07: 1)$.

\section{> GROWTH ESTIMATION AND BACK-CALCULATION}

The $T L-S L$ relationship for the total sample was:

$$
S L=0.086+0.872 T L\left(R^{2}=0.993, r=0.997, p<0.001\right)
$$

for females:

$$
S L=-0.084+0.872 T L\left(R^{2}=0.993 ; r=0.997 ; p<0.001\right)
$$

and for males:

$$
S L=-0.101+0.873 T L\left(R^{2}=0.991 ; r=0.995 ; p<0.001\right)
$$

with no statistical differences between the regressions for both sexes (ANCOVA: $F=1.554$, $p>0.05)$.

The $T L-W$ relationship for the total sample was:

$$
\log _{10} W=-2.384+3.210 \log _{10} T L\left(R^{2}=0.952 ; r=0.976 ; p<0.001\right)
$$




\section{Table I}

Mean back-calculated total length (TL in $\mathrm{cm}) \pm$ standard error (SE) at successive annuli for Atherina boyeri from Trasimeno lake. Back-calculated lengths derived from the last annulus were shown in bold.

\begin{tabular}{|l|c|c|c|c|c|}
\cline { 3 - 6 } \multicolumn{2}{c|}{} & \multicolumn{3}{|c|}{ Mean back-calculated $T L \pm$ SE at successive annulf } \\
\hline Age clas & N & $\mathbf{1}$ & $\mathbf{2}$ & $\mathbf{3}$ & 4 \\
\hline $\mathbf{1 +}$ & 78 & $\mathbf{4 . 1 0 8} \pm \mathbf{0 . 0 4 4}$ & & & \\
$\mathbf{2 +}$ & 92 & $4.288 \pm 0.029$ & $\mathbf{6 . 1 3 2} \pm \mathbf{0 . 0 4 3}$ & & \\
$\mathbf{3 +}$ & 46 & $4.314 \pm 0.031$ & $6.152 \pm 0.065$ & $\mathbf{7 . 6 9 5} \pm \mathbf{0 . 0 6 9}$ & \\
$\mathbf{4 +}$ & & $4.534 \pm 0.168$ & $6.461 \pm 0.047$ & $7.727 \pm 0.063$ & $\mathbf{8 . 4 1 0} \pm \mathbf{0 . 0 1 8}$ \\
mean & 21 & $4.232 \pm 0.022$ & $6.143 \pm 0.036$ & $7.697 \pm 0.066$ & $8.410 \pm 0.018$ \\
\hline
\end{tabular}

\section{Table II}

Lee's phenomenon for Atherina boyeri from Trasimeno: comparison of back-calculated total lengths between the specimens at age $t$ and $(t+i)$ and results of ANOVA.

\begin{tabular}{|l|c|c|c|c|c|c|}
\cline { 2 - 7 } \multicolumn{1}{c|}{} & \multicolumn{2}{c|}{ Age } & \multicolumn{2}{c|}{ Age $(t+i$} & \multicolumn{2}{c|}{ ANOVA } \\
\hline Age class & $N$ & Mean \pm SE & $N$ & Mean \pm SE & $F$ & $p$ \\
\hline $\mathbf{1 +}$ & 78 & $4.108 \pm 0.044$ & 140 & $4.300 \pm 0.021$ & 3.797 & 0.001 \\
$\mathbf{2 +}$ & 92 & $6.132 \pm 0.043$ & 48 & $6.165 \pm 0.063$ & 0.527 & 0.598 \\
$\mathbf{3 +}$ & 46 & $7.695 \pm 0.069$ & 2 & $7.727 \pm 0.063$ & 0.206 & 0.836 \\
\hline
\end{tabular}

for females:

$$
\log _{10} W=-2.326+3.139 \log _{10} T L\left(R^{2}=0.956 ; r=0.978, p<0.001\right)
$$

and for males:

$$
\log _{10} W=-2.366+3.168 \log _{10} T L\left(R^{2}=0.968 ; r=0.984, p<0.001\right)
$$

with significant differences between the sexes (ANCOVA: $F=18.933, p<0.01$ ). For the $t$-test, the $b$ (slope) value of the $T L-W$ regressions was significantly greater than 3 (for females, males and the total sample: $p<0.01$ ), indicating positive allometric growth (Ricker, 1975).

For females the $S_{r}-T L$ relationship was:

$$
T L=1.614+60.053 S_{r}\left(R^{2}=0.836 ; r=0.915 ; p<0.01\right)
$$

and for males:

$$
T L=1.090+65.005 S_{r}\left(R^{2}=0.785 ; r=0.886 ; p<0.01\right) .
$$

Because of no significant differences between the above regressions (ANCOVA: $F=1.002$; $p=0.318$ ), an overall equation for the total sample was computed as:

$$
T L=1.208+63.672 S_{r}\left(R^{2}=0.840 ; r=0.917 ; p<0.01\right)
$$

and used in subsequent analyses.

Scale analysis indicated the appearance of an annulus in April and mean BCLs at various ages were determined for the overall sample (Table I). Theoretical growth, calculated using the BCLs at the last annulus, was:

$$
T L_{t}=10.031\left\{1-\mathrm{e}^{[-0.443(t+0.180)]}\right\} \quad\left(R^{2}=0.998\right)
$$

with a $\Phi^{\prime}$ value of 1.649

Due to Lee's phenomenon, the length of specimens of age $(t+i)$ was higher than those of age $t$ for all the age classes (Table II). However, based on the U-Mann test, the differences between values were significant only for class $1+(Z=3.797 ; p<0.01)$, indicating the occurrence of a reverse Lee's phenomenon. Based on ANOVA, the mean BCLs at age 1 of the older specimens were significantly greater than those of the juveniles $(F=6.790 ; p<0.001)$. 

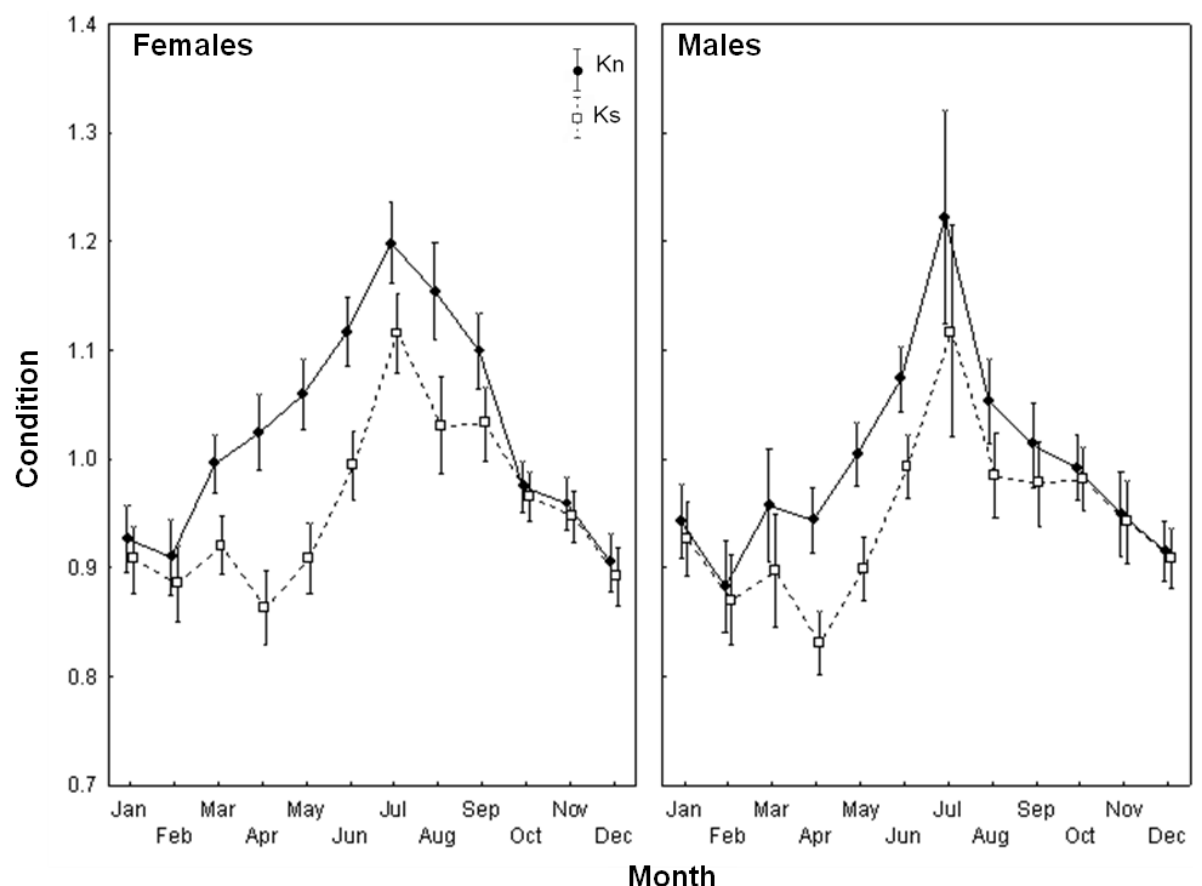

\section{Figure 4}

Trends of relative condition (Kn) and somatic relative condition (Ks) values throughout the year for Atherina boyeri in Trasimeno lake.

\section{> ESTIMATION OF BODY CONDITION}

The mean value of the condition factor $(K n \pm S E)$ for the overall sample was $1.019 \pm 0.158$, while that of the somatic condition factor $(K S \pm S E)$ was $0.940 \pm 0.115$.

Comparison between the sexes revealed that the mean value of $\mathrm{Kn}$ was slightly higher in females $(1.008 \pm 0.138)$ than in males $(0.975 \pm 0.113)$, and there were highly significant differences between the sexes $(t=15.867, p<0.001)$.

Similarly, for $K s$ the mean value for females $(0.947 \pm 0.116)$ was significantly higher than for males $(0.930 \pm 0.112)(t=5.265 ; p<0.05)$.

Upon comparison of the monthly trend of $K n$ and $K s$ for both sexes (Figure 4), there were no marked differences between the sexes: for both sexes, differences between $\mathrm{Kn}$ and $\mathrm{Ks}$ were greater from March to July (testifying the sharp increase in weight occurring during the reproductive period due to the gonad development), while from October to February Kn and Ks values were almost overlapping. Based on ANOVA, differences between monthly mean values were highly significant for both $K n(F=36.43, p<0.001)$ and $K s(F=22.49, p<0.001)$ and differences between monthly average values of $\mathrm{Kn}$ for sex were also highly significant $(F=$ 2.95, $p<0.001)$, whereas there were no significant differences for $K s(F=0.99, p>0.05)$.

Analysis of the females' GSI trend confirmed the above results (Figure 5): from October to February development of female gonads was almost absent and only from February did the GSI start to increase, reaching the highest average value in April (16\% of total body mass). From May onwards, the GSI value decreased and in August a second relative maximum was observed ( $10 \%$ of body weight). The minimum GSI value occurred in October, when the gonads enter a quiescent state until February.

\section{DISCUSSION}

Atherina boyeri is commercially exploited in several Mediterranean countries such as Croatia (Bartulovic et al., 2004), Greece (Leonardos and Sinis, 2000; Leonardos, 2001; Koutrakis 


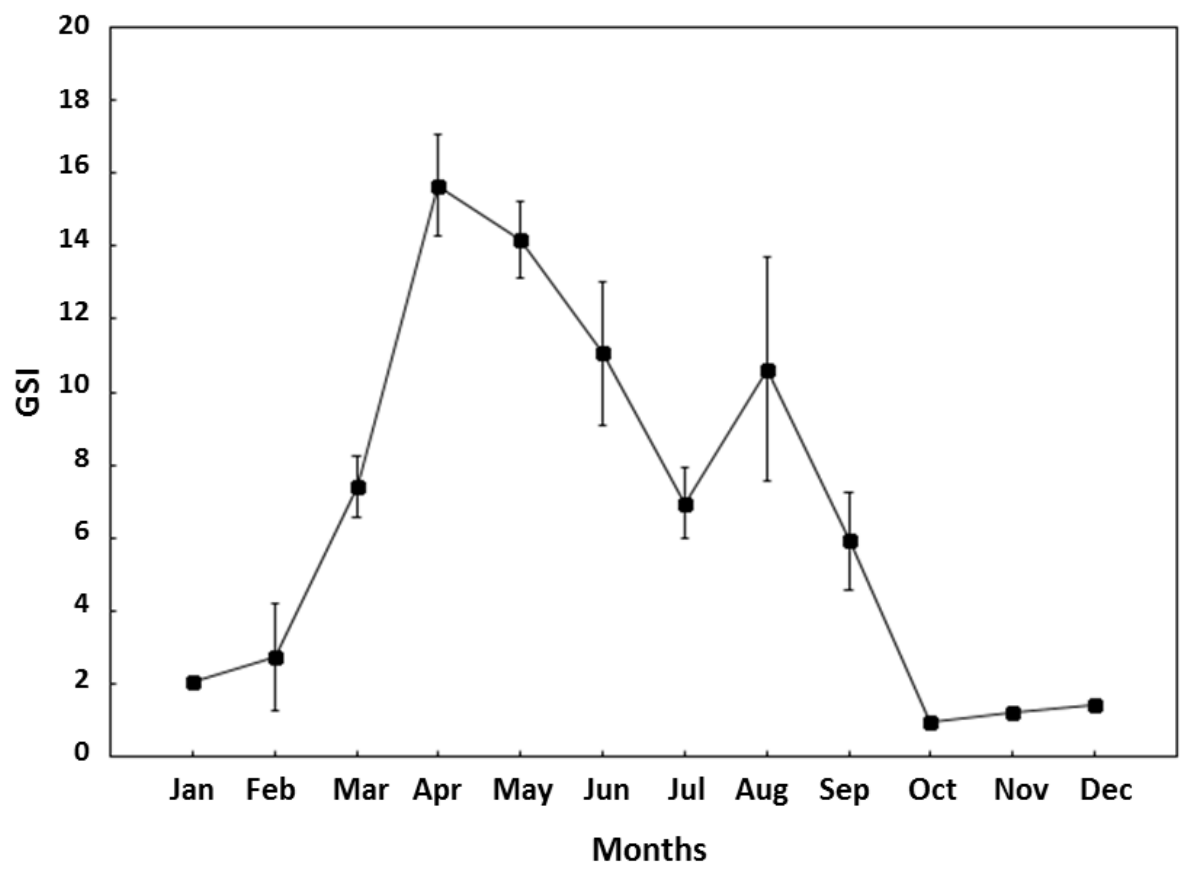

Figure 5

Monthly trend of gonadosomatic index (GSI) for females of Atherina boyeri in Trasimeno lake.

et al., 2004), Spain (Fernandez-Delgado et al., 1988), Turkey (Özeren, 2009) and also Italy (Boscolo, 1970; Mearelli et al., 1990; Lorenzoni and Ghetti, 2012). In Lake Trasimeno, the species was introduced in 1920 (Moretti et al., 1959) and it rapidly acclimated, increasing in abundance. Currently, the species is the most widely caught by local fishermen (Pompei et al., 2012a) and it has great value for the local economy.

However, currently information on the biology and ecology of this species in Lake Trasimeno and other Italian water bodies is limited.

In this study the estimated maximum age of $4+$ is consistent with with that reported for other populations of the species (Henderson et al., 1988; Leonardos, 2001; Pallaoro et al., 2002; Koutrakis et al., 2004; Özeren, 2009), whereas several other studies have indicated a maximum age of 2-3+ (Donato et al., 1996; Bertotto et al., 1997; Leonardos and Sinis, 2000; Andreu-Soler et al., 2003). Also, the maximum size of the Lake Trasimeno specimens was similar to that reported in other studies, with a total length of about $10 \mathrm{~cm}$ (Leonardos and Sinis, 2000; Andreu-Soler et al., 2003; Bartulovic et al., 2004; Chrisafi et al., 2007).

In Lake Trasimeno, females were longer, older and heavier than males, and this could be attributed to higher mortality of males as indicated by the sex ratio in favour of females with increasing age. Similarly, a sex ratio at the disadvantage of the males and a bigger size for females has been found in other populations of the species (Donato et al., 1996; Bertotto et al., 1997; Leonardos and Sinis, 2000; Özeren, 2009). Leonardos and Sinis (1999) reported that strategic mechanisms to protect females have been developed in many fish species and these can include selective predation of males, and greater longevity and greater survival of females during the spawning period. The same hypothesis was also confirmed by Koutrakis et al. (2004), who found a higher survival rate of females than males for the population of big-scale sand smelt of Vistonis Lake and Porto Lagos Lagoon (Greece). It can therefore be hypothesised that the scenario observed in Lake Trasimeno and in other water bodies where A. boyeri is present could result from these species' specific strategies.

The value of $b$ of the total length-weight equation was significantly higher than 3 (for both the total sample and individual sexes), indicating positive allometric growth for the big-scale sand smelt population of Lake Trasimeno. Comparing these values with those estimated for other 
Table III

Parameters of theoretical growth for different populations of Atherina boyeri from other Mediterranean countries.

\begin{tabular}{|c|c|c|c|c|c|c|c|}
\hline$\overline{T L_{t}}$ & $k$ & $\overline{t_{0}}$ & $\operatorname{sex}$ & $\theta^{\prime}$ & Country & Location & References \\
\hline 9.9 & 0.97 & -0.19 & $M$ & 1.98 & Croatia & $\begin{array}{l}\text { Mala Neretva River } \\
\text { estuary }\end{array}$ & Bartulovic et al., 2004 \\
\hline 10.6 & 1.19 & 0.01 & $\mathrm{~F}$ & 2.13 & Croatia & $\begin{array}{l}\text { Mala Neretva River } \\
\text { estuary }\end{array}$ & Bartulovic et al., 2004 \\
\hline 7.5 & 0.67 & -0.46 & M & 1.58 & Greece & $\begin{array}{l}\text { Mesolongi and } \\
\text { Etolikon lagoon }\end{array}$ & $\begin{array}{l}\text { Leonardos and Sinis, } \\
2000\end{array}$ \\
\hline 12 & 0.23 & -1.37 & $\mathrm{~F}$ & 1.52 & Greece & $\begin{array}{l}\text { Mesolongi and } \\
\text { Etolikon lagoon }\end{array}$ & $\begin{array}{l}\text { Leonardos and Sinis, } \\
2000\end{array}$ \\
\hline 12.3 & 0.38 & 0.02 & $\mathrm{M}, \mathrm{F}$ & 1.75 & Greece & Trichonis lake & Leonardos, 2001 \\
\hline 12.8 & 0.26 & -1.64 & $\mathrm{M}$ & 1.63 & Greece & Vistonis estuary & Koutrakis et al., 2004 \\
\hline 16.7 & 0.16 & -1.9 & $\mathrm{~F}$ & 1.65 & Greece & Vistonis estuary & Koutrakis et al., 2004 \\
\hline 10.03 & 0.18 & -0.44 & $M, F$ & 1.65 & Italy & Trasimeno lake & present study \\
\hline 8.2 & 0.91 & -0.45 & $\mathrm{M}$ & 1.79 & Spain & Mar Menor lagoon & $\begin{array}{l}\text { Andreu-Soler et al., } \\
2003\end{array}$ \\
\hline 8.5 & 0.81 & -0.61 & $\mathrm{~F}$ & 1.76 & Spain & Mar Menor lagoon & $\begin{array}{l}\text { Andreu-Soler et al., } \\
2003\end{array}$ \\
\hline 12.1 & 0.33 & -0.28 & $\mathrm{M}$ & - & Turkey & Iznik lake & Özeren, 2009 \\
\hline 14.1 & 0.27 & -0.49 & $M, F$ & - & Turkey & Iznik lake & Özeren, 2009 \\
\hline 15.5 & 0.21 & -0.73 & $\mathrm{~F}$ & - & Turkey & Iznik lake & Özeren, 2009 \\
\hline
\end{tabular}

environments (Table III), the growth for the big-scale sand smelt population of Lake Trasimeno can be regarded as slower compared with other populations.

Based on body condition, the overall health of the population was good, with a mean $\mathrm{Kn}$ very close to 1 (Bagenal and Tesh, 1985). Also, the overall condition of females was higher than that of males both for $K n$ and $K s$, and comparison between monthly values for both sexes revealed that the worst body condition occurred during the coldest season. This could probably be attributed to the decrease in water temperature and the paucity of food resources that normally occur during the colder months (Koutrakis et al., 2004). A similar trend in the bigscale sand smelt was also observed for other populations (Marfin, 1982; Fernandez-Delgado et al., 1988; Koutrakis et al., 2004; Andreu-Soler et al., 2006). These similarities could indicate that despite these populations inhabiting environments with different characteristics, energy allocation for reproduction, growth or fat storage during the year is determined by seasonality (Koutrakis et al., 2004).

Both analyses of the trends of $K n$ and $K s$ and the GSI of females suggested that reproduction in Trasimeno Lake took place from March to September, similarly to the results reported for other Mediterranean countries such as Croatia (Bartulovic et al. , 2004) and Greece (Leonardos and Sinis, 2000).

Analysis of back-calculated ages indicated the occurrence of a reverse Lee's phenomenon. This could be due to predation or competition, representing a disadvantage for young specimens ( $0+$ and $1+$ classes), causing slower growth and benefiting only the biggest specimens (Lorenzoni et al., 2002a). This was also proved upon comparison between the BCL at first annulus and that of older specimens, showing that the mean lengths of older specimens were significantly bigger than those of the younger ones.

The occurrence of selective mortality could penalise those specimens not able to access an adequate amount of food, especially during winter, when environmental conditions are more severe, thereby disadvantaging specimens that have not stored a sufficient supply of energy (Henderson et al., 1988). Further research on size selectivity and reproduction of the Lake Trasimeno population will be able to provide insights into these mechanisms.

Since the earlier years following introduction of $A$. boyeri into Lake Trasimeno, abundances and rates by professional fishermen have been very changeable. Historical data from 1935 to 1957 indicate a strong increase in the catch (with 102.8 tonnes ( $t$ ) in 1935 and $264.6 \mathrm{t}$ in 1937). In 1938, there was a dramatic fall in the abundance of the fishery (46 t), whereas 
from 1945 catches increased again (139 $t$ in 1947) (Moretti et al., 1959). In 1956-1980, the species was the sixth most caught (9\% of the total catch with $66.5 \mathrm{t}$ ), whereas in 1981-1986 the proportion drastically changed, with the species representing $20.59 \%$ of the total catch (Mearelli et al., 1990). In 1995-2004 A. boyeri represented the main component of the total catch (29\% of the total), despite variable annual values ranging from a minimum of $8.1 \mathrm{t}$ in 2004 to a maximum of 103.9 t in 2001 (Lorenzoni and Ghetti, 2012). Nowadays, the species represents more than $50 \%$ of the total catch (Pompei et al., 2012a).

The results of this study provide useful information for the management of this species which is an important component in the food web of the lake and, in addition to the local fishery, has also undergone a high rate of predation. As reported in previous studies, the big-scale sand smelt represents the main food source for several predator species in the lake such as European perch (Lorenzoni et al., 1993), pike (Lorenzoni et al., 2002a) and largemouth bass (Lorenzoni et al., 2002b). In this regard, the occurrence of a reverse Lee's phenomenon confirmed the presence of mechanisms disadvantaging the smaller specimens. Further studies focusing on the selectivity of the fishing gears will be useful to assess whether the fishery affects the growth and population dynamics of this species in Lake Trasimeno.

\section{ACKNOWLEDGEMENTS}

We would like to thank the professional fishermen of Lake Trasimeno for their help with catching the fish, and all the students and collaborators who joined the project. We are also grateful to the two anonymous referees for their valuable comments that helped to improve the previous version of the article. Moreover, we would like to thank Dr. Lorenzo Vilizzi for his valuable help with proofreading the article.

\section{REFERENCES}

Anderson R.O. and Neumann R.M., 1996. Length, weight and associated structural indices. In: Murphy B.R. and Willis D.W. (eds.), Fisheries techniques. American Fisheries Society, Bethesda, 447-483.

Andreu-Soler A., Oliva-Paterna F.J., Fernandez-Delgado C. and Torralva M., 2003. Age and growth of the sand smelt, Atherina boyeri (Risso 1810), in the Mar Menor coastal lagoon (SE Iberian Peninsula). J. Appl. Ichthyol., 19, 202-208.

Andreu-Soler A., Oliva-Paterna F.J. and Torralva M., 2006. Seasonal variations in somatic condition, hepatic and gonad activity of sand smelt Atherina boyeri (Teleostei, Atherinidae) in the Mar Menor coastal lagoon (SE Iberian Peninsula). Folia Zool., 55, 151-161.

Bagenal T.B., 1978. Fish production in fresh waters. Blackwell, Oxford, $250 \mathrm{p}$.

Bagenal T.B. and Tesch F.W., 1985. Age and growth. In: Bagenal T.B. (ed.), Fish production in fresh waters. Blackwell, London, 101-136.

Bartulovic V., Glamuzina B., Conides A., Dulcic J., Lucic D., Njire J. and Kozul V., 2004. Age, growth, mortality and sex ratio of sand smelt, Atherina boyeri Risso, 1810 (Pisces: Atherinidae) in the estuary of the Mala Neretva River (middle-eastern Adriatic, Croatia). J. Appl. Ichthyol., 20, 427-430.

Bertotto D., Marconato A. and Rasotto M.B., 1997. Population structure of Atherina boyeri from the Venetian Lagoon (Atherinidae). In: Proceeds of IX International Congress of European Ichthyologists Trieste, 24-30 August 1997, 101-109.

Bianco P.G., Caputo V., Ferrito V., Lorenzoni M., Nonnis Marzano F., Stefani F., Sabatini A. and Tancioni L., 2013. Atherina boyeri Risso, 1810. In: Rondinini C. et al. (eds.), Liste Rosse italiane. Available at http://www.iucn.it [accessed 10 Sep 2014].

Boscolo L., 1970. Osservazioni sulla biologia e sulla pesca dell'Atherina boyeri Risso 1810 (Osteichthyes, Atherinidae) vivente nelle acque dell'Alto Adriatico. Boll. Pesca. Piscic. Idrobiol., $25,61-79$.

Britton J.R., Cowx I.G. and Peirson G., 2004. Sources of error in the ageing of stocked cyprinids. Fisheries Manag. Ecol., 11, 415-417. 
Chrisafi E., Kaspiris P. and Katselis G., 2007. Feeding habits of sand smelt (Atherina boyeri, Risso 1810) in Trichonis Lake (Western Greece). J. Appl. Ichthyol., 23, 209-214.

Devries D.R. and Frie R.V., 1996. Determination of age and growth. In: Murphy B.R and Willis D.W. (eds.), Fisheries Techniques. American Fisheries Society, Bethesda, 483-512.

Donato A., Salpietro L., Specchi M. and Valli G., 1996. Alcune osservazioni preliminari sulla biologia riproduttiva, sulla struttura e biometria di una popolazione di Atherina boyeri Risso (Osteichtyes, Atheriniformes) del Lago di Ganzirri (Messina). In: Atti IV Convegno Nazionale AllAD, Riva del Garda, 1991, 117-134.

Economidis P.S., Dimitriou E., Pagoni R., Michaloudi E. and Natsis L., 2000. Introduced and translocated fish species in the inland waters of Greece. Fisheries Manag. Ecol., 7, 239-250.

Fernandez-Delgado C., Hernando J.A., Herrera M. and Bellido M., 1988. Life-history patterns of the sand smelt Atherina boyeri Risso, 1810 in the estuary of the Guadalquivir river, Spain. Est. Coast. Mar. Sci., 27, 69-706.

Francisco S.M., Congiu L., Stefanni S., Castilho R., Brito A., Ivanova P.P., Levy A., Cabral H., Kilias G., Doadrio I. and Almada V., 2008. Phylogenetic relationships of the North-eastern Atlantic and Mediterranean forms of Atherina (Pisces, Atherinidae). Mol. Phylogenet. Evol., 48, 78-788.

Freyhof J. and Kottelat M., 2008. Atherina boyeri. In: IUCN Red List of Threatened Species. IUCN 2012. (Version 2012.2). Available at: http: www.iucnredlist.org [accessed 20 August 2014].

Giovanardi F., Poletti A. and Micheli A., 1995. Indagine sulla qualità delle acque del lago Trasimeno. Definizione dei livelli trofici. Acqua Aria, 6, 627-633.

Henderson P.A., Holmes R.H.A. and Bamber R.N., 1988. Size-selective overwintering mortality in the sand smelt, Atherina boyeri Risso, and its role in population regulation. J. Fish Biol., 33, 221-233.

Kestemont P. and Philippart J.C., 1991. Patterns of oocyte growth in fish with synchronous and asynchronous oogenesis. Belg. J. Zool., 121, 87-98.

Koutrakis E.T., Kamidis N.I. and Leonardos I.D., 2004. Age, growth and mortality of a semi-isolated lagoon population of sand smelt, Atherina boyeri (Risso, 1810) (Pisces: Atherinidae) in an estuarine system of northern Greece. J. Appl. Ichthyol., 20, 382-388.

Le Cren E.D., 1951. The length relationship and seasonal cycle in gonad weight and condition in the perch (Perca fluviatilis). J. Anim. Ecol., 20, 210-218.

Leonardos I.D., 2001. Ecology and exploitation pattern of a landlocked population of sand smelt, Atherina boyeri (Risso 1810), in Trichonis Lake (western Greece). J. Appl. Ichthyol., 17, 1-5.

Lorenzoni M., Giovinazzo G., Mearelli M. and Natali M., 1993. Growth and biology of perch (Perca fluviatilis L.) in Lake Trasimeno (Umbria, Italy). Pol. Arch. Hydrobiol., 40, 313-328.

Leonardos I.D. and Sinis A., 1999. Population age and sex structure of Aphanius fasciatus (Nardo, 1827) (Pisces: Cyprinodontidae) in the Mesolongi and Etolikon lagoons (W. Greece). Fish Res., 40, 227-235.

Leonardos I.D. and Sinis A., 2000. Age, growth and mortality of Atherina boyeri Risso, 1810 (Pisces: Atherinidae) in the Mesolongi and Etolikon lagoons (W. Greece). Fish Res., 45, 81-91.

Lorenzoni M., Corboli M., Dörr A.J.M., Mearelli M. and Giovinazzo G., 2002a. The growth of pike (Esox lucius Linnaeus, 1798) in lake Trasimeno (Umbria, Italy). Fish Res., 59, 239-246.

Lorenzoni M., Dörr A.J.M., Erra R., Giovinazzo G., Mearelli M. and Selvi S., 2002b. Growth and reproduction of largemouth bass (Micropterus salmoides Lacepede, 1802) in Lake Trasimeno (Umbria, Italy). Fish Res., 56, 89-95.

Lorenzoni M., Ghetti L. and Mearelli M., 2006. Native and exotic fish species in the Tiber River watershed (Umbria-Italy) and their relationship to the longitudinal gradient. Bull. Fr. Pêche Piscic., 382, 19-44.

Lorenzoni M., Corboli M., Ghetti L., Pedicillo G. and Carosi A., 2007. Growth and reproduction of the goldfish Carassius auratus: a case study from Italy. In: Gherardi F. (ed.), Biological invaders in inland waters: profiles, distribution and threats, 259-274. Springer Book, Dordrecht.

Lorenzoni M., Ghetti L., Carosi A. and Dolciami R., 2010. La fauna ittica e i corsi d'acqua dell'Umbria. Regione Umbria, Perugia, $300 \mathrm{p}$.

Lorenzoni M. and Ghetti L., 2012. Evoluzione della fauna ittica e problematiche gestionali del lago Trasimeno. In: Martinelli (ed.), Libri Arpa Umbria: Perugia, Tutela ambientale del Lago Trasimeno, 131-145.

Mantilacci L., Mearelli M., Giovinazzo G. and Lorenzoni M., 1990. Accrescimento e alimentazione del latterino (Atherina boyerii Risso) del lago Trasimeno. Rivista d'Idrobiologia, 29, 30-327. 
Marfin J.P., 1982. Croissance de l'Atherine Atherina boyeri Risso, 1810 dans trois milieux saumatres du Roussillon. Bull. Inst. Natl. Sci. Tech. Oceanogr. Peche Salammbo, 9, 89-109.

Mearelli M., Lorenzoni M. and Ruffini F., 1981. Determinazione dello stato trofico del lago Trasimeno attraverso la valutazione indiretta dell'azoto e del fosforo. Rivista d'ldrobiologia, 20, 572-587.

Mearelli M., Lorenzoni M. and Mantilacci L., 1990. II lago Trasimeno. Rivista d'Idrobiologia, 29, 353-390.

Moretti G.P., Gianotti F.S. and Giganti A., 1959. II latterino (Atherina mochon Cuv.) nel Trasimeno (biometria, regime dietetico, pesca e parassitismo). Rivista d'ldrobiologia, 11, 3-38.

Özeren S.C., 2009. Age, Growth and Reproductive Biology of the Sand Smelt Atherina boyeri, Risso 1810 (Pisces: Atherinidae) in Lake Ýznik, Turkey. J. Int. Fisheries, 4, 34-39.

Pallaoro A., Franieevie M. and Matie S., 2002. Age, growth and mortality of big-scale sand smelt, Atherina (Hepsetia) boyeri Risso, 1810 in the Pantana Lagoon, Croatia. Periodicum Biological, 104, 175-183.

Pauly D. and Munro J.L., 1984. Once more on comparison of growth in fish and invertebrates. ICLARM Fishbyte, 1, 21-22.

Pompei L., Carosi A., Dolciami R., Ghetti L., Giannetto D., Natali M. and Lorenzoni M., 2012a. Monitoring plan of catch and fishing effort in Trasimeno Lake (Umbria, Italy): Preliminary results. In: VI World Fisheries Congress, Edinburg, 12-16 May 2012. Book of Abstract p. 178.

Pompei L., Franchi E., Giannetto D. and Lorenzoni M., 2012b. Growth and reproductive properties of Tench, Tinca tinca Linnaeus, 1758 in Trasimeno Lake (Umbria, Italy). Knowl. Manag. Aquat. Ecosyst., 406, 1-13.

Quignard J.P. and Pras A., 1986. Atherinidae. In: Whitehead P., Bauchot M.L., Hureau J.C., Nielsen J. and Tortonese E. (eds.). Fishes of the North-eastern Atlantic and Mediterranean. UNESCO, Paris, 1207-1210.

Ricker W.E., 1975. Computation and interpretation of biological statistics of fish populations. J. Fish Res. Board Can., 191, 1-382.

Rosecchi E. and Crivelli A.J., 1992. Study of a sand smelt (Atherina boyeri Risso 1810) population reproducing in freshwater. Ecol. Freshw. Fish, 1, 77-85.

Vaughan D.S. and Burton M.L., 1994. Estimation of von Bertalanffy growth parameters in the presence of size-selective mortality: a simulated example with red grouper. T. Am. Fish Soc., 123, 1-8.

Von Bertalanffy L., 1938. A quantitative theory of organic growth. Human Biology, 10, 181-243.

Whitehead P.J.P., Bauchot M.L., Hureau J.C., Nielsen J. and Tortonese E., 1986. Fishes of the northeastern Atlantic and the Mediterranean. UNESCO, Paris.

Cite this article as: M. Lorenzoni, D. Giannetto, A. Carosi, R. Dolciami, L. Ghetti, L. Pompei, 2015. Age, growth and body condition of big-scale sand smelt Atherina boyeri Risso, 1810 inhabiting a freshwater environment: Lake Trasimeno (Italy). Knowl. Manag. Aquat. Ecosyst., 416, 09. 